\title{
Metabolites from nematophagous fungi and nematicidal natural products from fungi as alternatives for biological control. Part II: metabolites from nematophagous basidiomycetes and non-nematophagous fungi
}

\author{
Thomas Degenkolb $^{1}$ • Andreas Vilcinskas ${ }^{1,2}$
}

Received: 4 October 2015 / Revised: 29 November 2015 / Accepted: 2 December 2015 / Published online: 4 January 2016

(C) The Author(s) 2016. This article is published with open access at Springerlink.com

\begin{abstract}
In this second section of a two-part mini-review article, we introduce 101 further nematicidal and non-nematicidal secondary metabolites biosynthesized by nematophagous basidiomycetes or nonnematophagous ascomycetes and basidiomycetes. Several of these compounds have promising nematicidal activity and deserve further and more detailed analysis. Thermolides $\mathrm{A}$ and $\mathrm{B}$, omphalotins, ophiobolins, bursaphelocides $\mathrm{A}$ and $\mathrm{B}$, illinitone $\mathrm{A}$, pseudohalonectrins $\mathrm{A}$ and $\mathrm{B}$, dichomitin $\mathrm{B}$, and caryopsomycins $\mathrm{A}-\mathrm{C}$ are excellent candidates or lead compounds for the development of biocontrol strategies for phytopathogenic nematodes. Paraherquamides, clonostachydiol, and nafuredins offer promising leads for the development of formulations against the intestinal nematodes of ruminants.
\end{abstract}

Keywords Phytoparasitic nematodes - Nematicides · Nematophagous fungi $\cdot$ Secondary metabolites $\cdot$ Biocontrol

Andreas Vilcinskas

Andreas.Vilcinskas@agrar.uni-giessen.de

1 Institute for Insect Biotechnology, Justus-Liebig-University of Giessen, Heinrich-Buff-Ring 26-32, D-35392 Giessen, Germany

2 Department of Bioresources, Fraunhofer Institute for Molecular Biology and Applied Ecology, Winchester Strasse 2,

D-35394 Giessen, Germany

\section{Introduction}

Metabolites from nematophagous basidiomycetes

\section{General remarks}

The chemical ecology of nematophagous fungi is still far from understood. Little has been done to screen for metabolites in nematophagous fungi, or nematicidal metabolites in other fungi, since the pioneering studies by Stadler and colleagues published in the 1990s (Stadler et al. 1993a, b, 1994a, b, c, d). In the first part of this review, we discussed 83 primary and secondary metabolites from nematophagous ascomycetes (Degenkolb and Vilcinskas, in press). In this second installment, we consider nematicidal metabolites from nematophagous basidiomycetes and from those fungi that are currently regarded as non-nematophagous species. The numbering system for the compounds introduced here begins at 84 to provide continuity with the first part of the review.

Given that species parasitizing nematodes or their eggs are found in all major fungal phyla including Chytridiomycota, Ascomycota, Basidiomycota, and also the Zoopagomycotina and Mucormycotina, ${ }^{1}$ multiple and independent evolution of nematophagy was hypothesized (Barron 1977). The scenario of nematode-fungus associations may be far more complex than previously thought. This was recently exemplified by Morris and Hajek (2014) who reported on the parasitic nematode Deladenus siricidicola (Tylenchida: Neotylenchidae), which is used for biocontrol of the invasive pine-killing woodwasp Sirex noctilio (Hymenoptera: Siricidae). In its mycophagous phase, $D$. siricidicola feeds exclusively on the

\footnotetext{
$\overline{{ }^{1} \text { Incertae sedis }}$, formerly belonging to the traditional Zygomycota.
} 
growing hyphal tips of its basidiomycete host Amylostereum areolatum (Russulales: Amylostereaceae). The presence of woodwasp larvae triggers the nematode to change its life style - it invades the wasp larvae and sterilizes most of them. Notably, the white-rot fungus, which has so far been thought to serve as food source for Deladenus sp., was also shown to (1) invade the vulva of adult female mycophagous nematodes and (2) to kill and invade nematode eggs. Eggs were parasitized by the hyphal tips of the fungus whereas cystidia seemed to colonize the vulva of adults. It remains to be clarified if a toxin is also involved in the infection process,

Authors are aware of the fact that missing evidence does not necessarily imply a non-nematophagous life style of a fungus. However, for reasons of convenience and consistency with literature, we prefer to retain the terminus "nonnematophagous" for those associations without evidence for nematophagy.

\section{Metabolites from the genus Pleurotus}

The small but monophyletic family Pleurotaceae comprises nematophagous white-rot fungi (Thorn et al. 2000; Kirk et al. 2008). Members of the genus Pleurotus, such as the oyster mushroom Pleurotus ostreatus, have been shown to secrete tiny toxin-containing droplets, which effectively paralyze a nematode without killing it within $30 \mathrm{~s}$ of contact. The prey is subsequently penetrated by the fungal trophic hyphae and digested within $24 \mathrm{~h}$ (Thorn and Barron 1984; Barron and Thorn 1987).

The first nematicidal compound isolated from the genus Pleurotus was (E)-2-decenedioic acid (84). P. ostreatus NRRL 3526 (= ATCC 90520) was grown for 30 days at room temperature $\left(21-23^{\circ} \mathrm{C}\right)$ on autoclaved, damp wheat straw. Thereafter, an aqueous extract of the colonized substrate was filtered, and the filtrate was freeze-dried. After reconstitution of the lyophilizate in water, the organic fraction of the extract was further purified, finally by HPLC of the acetone-soluble fraction. The nematicidal principle, compound $\mathbf{8 4}$, which eluted as a single peak, was characterized by MS and NMR. An aqueous solution of pure 84 at a concentration of $300 \mu \mathrm{g} / \mathrm{ml}$ caused the immobilization of $95 \%$ of a test population of the nematode Panagrellus redivivus within $1 \mathrm{~h}$. Notably, this effect could not be reversed by rinsing the treated nematodes with deionized water. Organic extracts of a static straw culture have not been prepared and investigated for possible nematicidal activity (Kwok et al. 1992).

Six further nematicidal compounds $(\mathbf{1}, \mathbf{8 5}-\mathbf{8 9})$ were isolated from an 11-day fermentation of the pale oyster Pleurotus pulmonarius. All of the compounds were found in the mycelial extracts, whereas the culture broth only contained compounds 86-89. Compound 85 was $(S)-(9 Z, 11 E)$-13-hydroxy9,11-octadecadienoic acid (also known as $S$-coriolic acid), and this along with compound $\mathbf{1}$ (linoleic acid) exhibited the most potent nematicidal activity. The median lethal concentrations $\left(\mathrm{LC}_{50}\right)$ against Caenorhabditis elegans were less pronounced for $p$-anisaldehyde (86), $p$-anisyl alcohol (87), 1-(4methoxyphenyl)-1,2-propanediol (88), and 2-hydroxy (4'methoxy)-propiophenone (89). However, these four compounds were produced in comparatively large amounts, so they certainly contribute to the nematicidal repertoire of the producer (Stadler et al. 1994a). The direct application of nematicidal Pleurotus spp. to the soil (Thorn and Barron 1984; Barron and Thorn 1987) should therefore be considered as a potentially cost-effective approach for the biocontrol of phytoparasitic nematodes (Palizi et al. 2009).

Three nematicidal compounds were isolated using bioassay-guided fractionation from a 10-day submerged culture of Pleurotus eryngii var. ferulae L14, a subspecies associated with Ferlua communis subsp. communis, the giant fennel (Mang and Figliuolo 2010). Cheimonophyllon E (90), a colorless amorphous solid, was obtained from an ethyl acetate extract of the culture filtrate. A yellowish amorphous solid, $5 \alpha, 8 \alpha$-epidioxyergosta-6,22-dien-3- $\beta$-ol (91), and a colorless amorphous solid, 5-hydroxymethyl-furancarbaldehyde (92), were detected in the mycelium acetone extract. The $\mathrm{LC}_{50}$ values of compounds 90-92 against the pine wood nematode (Bursaphelenchus xylophilus) were 70.8, 174.6, and $54.7 \mathrm{mg} /$ 1, respectively, after $72 \mathrm{~h}$. The $\mathrm{LC}_{50}$ values against $P$. redivivus were $125.6,128.1$, and $82.8 \mathrm{mg} / \mathrm{l}$, respectively, after the same exposure (Li et al. 2007).

\section{Metabolites from the genera Coprinus and Coprinellus}

The nematophagous fungus Coprinus comatus (Agaricales, Coprinaceae), commonly known as the Shaggy Inkcap or Lawyer's Wig, forms spiny balls that enhance its nematicidal activity by mechanically damaging the nematode cuticle, ultimately leading to the loss of pseudocoelomic fluid (Luo et al. 2004, 2007). Agar cultures of C. comatus C-1 yielded a mixture of nematicidal secondary metabolites after cultivation on potato-dextrose agar at $25^{\circ} \mathrm{C}$ for 15 days. Seven compounds were obtained from organic extracts, namely 5-methylfuran-3carboxylic acid (93), 5-hydroxy-3,5-dimethylfuran-2 $(5 H)$ one (94), 5-hydroxy-3-(hydroxymethyl)-5-methylfuran-2 (5H)-one (95), 4,6-dihydroxyisobenzofuran-1,3-dione (96), 4,6-dihydroxybenzofuran-3 (2H)-one (97), 4,6dimethoxyisobenzofuran-1 (3H)-one (98) and 3-formyl-2,5dihydroxybenzyl acetate (99). Compounds 93 and 94 displayed the most potent nematicidal activity against Meloidogyne incognita and Panagrellus redivivus, with $\mathrm{LD}_{50}$ and $\mathrm{LD}_{90}$ values of 100 and $200 \mu \mathrm{g} / \mathrm{ml}$, respectively, for both compounds (Luo et al. 2007).

Organic extracts of Coprinus (now Coprinellus) xanthothrix (Agaricales, Psathyrellaceae) 4916 agar cultures yielded three further nematicidal metabolites: xanthonone (100), 7,8,11-drimanetriol (101) and 2-(1H-pyrrol-1-yl)- 
ethanol (102). The $\mathrm{LD}_{50}$ values of compounds $\mathbf{1 0 0}$ and $\mathbf{1 0 2}$ were 250 and $125 \mu \mathrm{g} / \mathrm{ml}$, respectively, against both $M$. incognita and $P$. redivivus, whereas compound $\mathbf{1 0 1}$ was practically inactive (Liu et al. 2008).

\section{Metabolites from the genus Nematoctonus}

Nematoctonus robustus, the anamorph of Hohenbuehelia grisea $^{2}$ (Agaricales, Pleurotaceae), is able to trap nematodes conidia, which form sticky knobs upon germination (Dowe 1987). $N$. robustus CBS 945.69 was grown in a fermenter at $24{ }^{\circ} \mathrm{C}$ for 11 days until the antimicrobial activities of the extracts did not increase any further. The bioactive principle consisted of dihydropleurotinic acid (103) and pleurotin (104), two 1,4-naphthoquinone antibiotics, and leucopleurotin (105), a precursor thereof. Biosynthesis of pleurotin involves a farnesylhydroquinone intermediate which is further cyclized, rearranged, and oxidized (Gill and Steglich 1987). Compounds 103-105 displayed weak antifungal activities and medium-toweak activities against bacteria and yeasts. None of the three quinones was nematicidal for C. elegans (Stadler et al. 1994b); however, effects toward other nematode species have not been reported so far. Notably, pleurotin was shown to act as an inhibitor of the thioredoxin-thioreductase system (Welsh et al. 2003). Subsequently, different species of pleurotin-producing basidiomycetes were investigated, and a fermentation protocol was developed to obtain this anticancer lead metabolite in concentrations $>300 \mathrm{mg} / \mathrm{l}$ (Shipley et al. 2006). A total synthesis of 104 and 105 was also reported (Hart and Hunag 1988).

Nematicidal metabolites from nematophagous basidiomycetes as well as compounds $\mathbf{1 0 3 - 1 0 5}$ are illustrated in Fig. 1.

\section{Metabolites from non-nematophagous ascomycetes}

\section{Nematicidal metabolites from Lachnum papyraceum}

The wood-inhabiting fungus L. papyraceum (Helotiales, Hyaloscyphaceae) A 48-88 is probably the most thoroughly investigated producer of nematicidal secondary metabolites. Five nematicidal substances were isolated from an 18-day fermentation culture filtrate, all displaying cytotoxic, antimicrobial, and nematicidal activities against $C$. elegans but not $M$. incognita (Stadler et al. 1993a; Anke et al. 1995). Three were identified as the previously known compounds (+)-mycorrhizin A (106), (+)-chloromycorrhizin A (107) and (1E)dechloromycorrhizin A (108), but two novel compounds were isolated as colorless substances, the crystalline lachnumon

\footnotetext{
${ }^{2}$ Hohenbuehelia spp. capture nematodes by hourglass-shaped sticky traps (Dowe 1987). The anamorph-teleomorph combination Nematoctonus/Hohenbuehelia forms a monophyletic, yet diverse clade within the Pleurotaceae (Koziak et al. 2007).
}

(109) and the oily lachnumol A (110), both of which contained a rare chlorinated 5,6-epoxide. Both compounds are therefore highly sensitive to oxygen and acid, and even aqueous or methanolic solutions were highly unstable. Under these conditions, the epoxy group opens to form a reactive cation, leading to further, rapid decomposition (Stadler et al. 1993b). Because chlorine substitution in compounds of terrestrial origin is comparatively rare, the influence of a bromide supplement on the secondary metabolism of strain A 48-88 was investigated. The addition of $5 \mathrm{mM} \mathrm{CaCl}_{2}$ and $50 \mathrm{mM} \mathrm{CaBr}_{2}$ to the uninoculated fermentation medium led to unexpected changes in the metabolite profile. Notably, chloromycorrhizin A (107), (1E)dechloromycorrhizin A (108), and lachnumon (109) were not detected anymore, and only traces of mycorrhizin (106) and lachnumol (110) were present. However, six novel metabolites bearing a dihydroisocoumarin (isochroman-1-one) skeleton were identified: 6,8-dihydroxy-3-methylisochroman-1-one (6hydroxymellein, 111), 4-chloro-6-hydroxymellein (112), 4bromo-6-hydroxymellein (113), 6-methoxymellein (114), 4chloro-6-methoxymellein (115), and 4-chloro-6,7dihyroxymellein (116). All six compounds were only weakly nematicidal (Stadler et al. 1995a, b). The addition of $\mathrm{CaBr}_{2}$ following the detection of (1E)-dechloromycorrhizin A (108) after 10 days of fermentation resulted in further diversification of the secondary metabolite profile. Brominated analogs named mycorrhizin B1 (117), mycorrhizin B2 (118), lachnumon B1 (119), and lachnumon B2 (120) were identified, and their activity was found to be slightly lower than their chlorinated counterparts (Stadler et al. 1995c, d). In addition to a stereoisomer of compound 108, four non-halogenated compounds were isolated, namely (1Z)-dechloromycorrhizin A (121) and the three novel mycorrhizin-related analogs papyracons A, B, and $C$ (122-124) which showed mutagenic activity in the Ames test (Stadler et al. 1995c, e). Further minor compounds were isolated with weak nematicidal activity against $C$. elegans (Shan et al. 1996): papyracon D (125), 6-O-methylpapyracon B (126), 6-O-methylpapyracon $\mathrm{C}$ (127), lachnumfuran A (128), lachnumlactone A (129), and chloromycorrhizinol A (130). This detailed analysis of the "nematicidal fraction" of $L$. papyraceum A 48-88 also revealed the susceptibility of $C$. elegans to a broad range of metabolites. Bioassay-guided screening for nematicidal compounds should therefore be carried out using economically important phytoparasitic nematodes (Anke et al. 1995). The impressive arsenal of nematicidal metabolites from the non-nematophagous ascomycete $L$. papyraceum is summarized in Fig. 2.

\section{Bulgarialactones from Bulgaria inquinans A 40-94}

The black bulgar (Bulgaria inquinans), a saprotrophic ascomycete (Phacidiales, Phacidiaceae), grows on the bark of decaying deciduous trees and logs, preferably on oak. An organic extract of fruiting bodies yielded three azaphilones, 


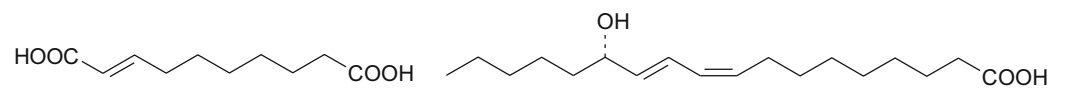

(E)-2-decenedioic acid (84)

(S)-coriolic acid (85)<smiles>COc1ccc(CO)cc1</smiles>

$86 \quad 87$<smiles>COc1ccc(C(=O)C(C)O)cc1</smiles><smiles>O=C1C=CC(=O)C2=C1CC1C(C(=O)O)CCC3C4CCCCC43[C@@H]21</smiles>

86: $p$-anisaldehyde

87: $p$-anisyl alcoho

88: 1-(4-methoxyphenyl)-1,2-propanediol

89. 2-hydroxy(4'-methoxy)-propiophenone

91: $5 \Delta, 8 \Delta$-epidioxyergosta-6,22-dien-3- $\Delta$-ol

92: 5-hydroxymethyl-furancarbaldehyde

93: 5-methylfuran-3-carboxylic acid

94: 5-hydroxy-3,5-dimethylfuran-2(5H)-one

95: 5-hydroxy-3-(hydroxymethyl)-5-methylfuran-2(5H)-one

96: 4,6-dihydroxyisobenzofuran-1,3-dione

97: 4,6-dihydroxybenzofuran-3(2H)-one

98: 4,6-dimethoxyisobenzofuran-1(3H)-one

99: 3-formyl-2,5-dihydroxybenzyl acetate

100: xanthonone

101: 7,8,11-drimanetriol

102: 2-(1H-pyrrol-1-yl)-ethanol

103: dihydropleurotinic acid

104: pleurotin

105: leucopleurotin

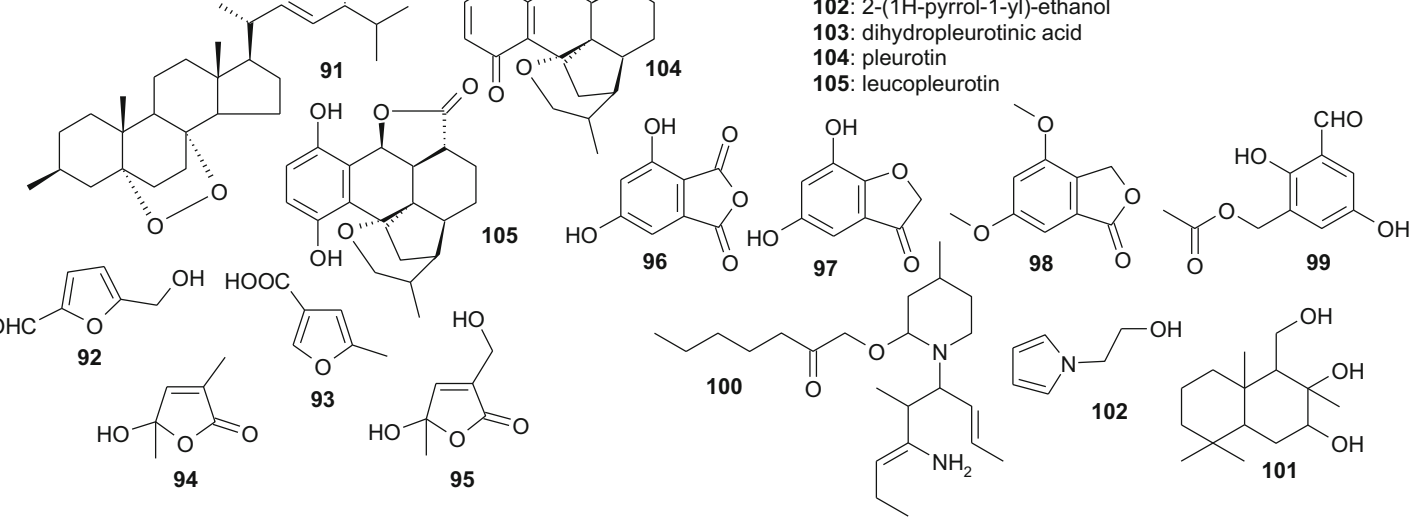

Fig. 1 Nematicidal metabolites from nematophagous basidiomycetes. See comments on compounds $\mathbf{1 0 3 - 1 0 5}$ within the text

named bulgarialactones A, B, and C (131-133), but only compound 132 could be isolated in sufficient quantities for further analysis. The mycelia of an 11-day submerged culture of

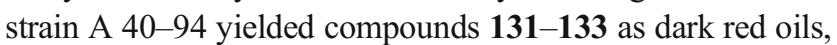
whereas organic extracts of the culture filtrate yielded only compound 132 in preparative amounts. The $\mathrm{LD}_{50}$ values of compounds 131 and 132 against $C$. elegans were 5 and 10$25 \mu \mathrm{g} / \mathrm{ml}$, respectively, whereas compound (133) could not be tested due to its instability and low yield (Stadler et al. 1995f).

\section{Thermolides from Talaromyces thermophilus ${ }^{3}$ YM 3-4}

Submerged cultures of the thermophilc fungus Talaromyces thermophilus YM 3-4 were grown for 21 days at $45^{\circ} \mathrm{C}$, yielding six colorless oils, named thermolides A-F (134-139). These provided the first evidence for a hybrid polyketide synthase non-ribosomal peptide synthetase (PKS-NRPS) of fungal origin (Niu et al. 2014). ${ }^{4}$ All thermolides feature an unusual 13-membered lactam-bearing macrolactone ring system.

\footnotetext{
${ }^{3}$ The fungus has recently been reclassified as Thermomyces dupontii. Penicillium dupontii and Talaromyces thermophilus are used synonymously. Both thermolide-producing species mentioned here belong to the Trichocomaceae, according to their ITS sequences (Houbraken et al. 2014).

${ }^{4}$ A related compound, thermolide $\mathrm{G}(\mathbf{1 4 0})$, has recently been isolated from Thermomyces lanuginosus (strains G5 and ATCC 200065), but no information about its nematicidal activity is available (Niu et al. 2014).
}

Thermolides A (134) and B (135) exhibited strong nematicidal activities with $\mathrm{LC}_{50}$ values against $M$. incognita, Bursaphelenchus xylophilus ${ }^{5}$ and $P$. redivivus as high as those of the avermectin standard, ranging from 0.5 to $1.0 \mu \mathrm{g} / \mathrm{ml}$. Thus, thermolides $\mathrm{A}$ and $\mathrm{B}$ but also the less bioactive thermolides $\mathrm{C}(\mathbf{1 3 6})$ and $\mathrm{D}(\mathbf{1 3 7})^{6}$ may serve as lead candidates for the development of new biological nematicides (Guo et al. 2012).

\section{Paraherquamides from Penicillium charlesii ATCC 20841}

Seven oxindole alkaloids, paraherquamides $A-G$ (141147), were isolated from 7- or 14-day static cultures of Penicillium charlesii ATCC 20841 grown at $25{ }^{\circ} \mathrm{C}$. The major compound paraherquamide A (141) was also the most active one, with an $\mathrm{LD}_{50}$ value of $2.5 \mu \mathrm{g} / \mathrm{ml}$ against $C$. elegans (141). The $\mathrm{LD}_{50}$ values of the other compounds ranged from $6 \mu \mathrm{g} / \mathrm{ml}$ (145) to $160 \mu \mathrm{g} / \mathrm{ml}$ (144). Broad-spectrum activity was observed against the three pathogenic nematodes Haemonchus contortus, Trichostrongylus colubriformis, and T. sigmodontis, each of them located in a distinct part of the gastrointestinal tract of the gerbil, Meriones unguiculatus (Ostlind et al.

\footnotetext{
${ }^{5}$ Mis-spelled as Bursaphelenches siylopilus by Guo et al. (2012).

${ }^{6}$ No information concerning the nematicidal activities of thermolides E and $\mathrm{F}$ is available because only minute amounts have been isolated (Guo et al. 2012).
} 
Fig. 2 Nematicidal metabolites from the non-nematophagous ascomycete Lachnum papyraceum<smiles>[R1]C1=C[C@H](OC)[C@H](C)[C@@]23O[C@]12[R2]3([R])CC</smiles><smiles>[R1]Oc1cc(O)c2c(c1[R2])C([R3])C(C)OC2=O</smiles><smiles>[R2]C(=CC)C1=C([R])C(=O)[C@]2(C)[C@H](O)[C@H](C)C(C)(C)O[C@@]12C</smiles>

106: mycorrhizin A

107: chloromycorrhizin A

108: (1E)-dechloromycorrhizin $A$

121: (1Z)-dechloromycorrhizin $A$

117: mycorrhizin $B 1$

118: mycorrhizin $B 2$

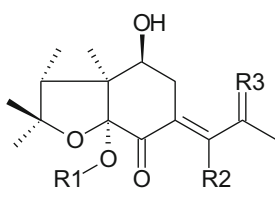

122: papyracon $A$

123: papyracon $B$

(stereoisomer of 123)

126: 6-O-methylpapyracon B

127: 6-O-methylpapyracon $C$

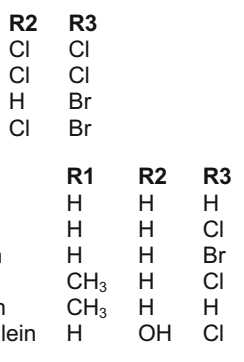

$\begin{array}{ll}\text { R1 } & \text { R2 } \\ \mathrm{H} & \mathrm{Cl} \\ \mathrm{Cl} & \mathrm{Cl} \\ \mathrm{H} & \mathrm{H} \\ \mathrm{H} & \mathrm{H} \\ \mathrm{H} & \mathrm{Br} \\ \mathrm{Cl} & \mathrm{Br}\end{array}$

$\begin{array}{lll}\text { R1 } & \text { R2 } & \text { R3 } \\ \mathrm{H} & \mathrm{H} & \mathrm{O} \\ \mathrm{H} & \mathrm{H} & \mathrm{OH}, \mathrm{H} \\ \mathrm{H} & \mathrm{H} & \mathrm{H}, \mathrm{OH} \\ & \\ \mathrm{CH}_{3} & \mathrm{H} & \mathrm{OH}, \mathrm{H} \\ \mathrm{CH}_{3} & \mathrm{H} & \mathrm{H}, \mathrm{OH}\end{array}$

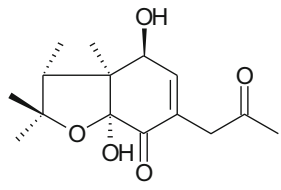

papyracon D (125)<smiles>Cc1cc2c(o1)C(=O)C1(CC1C(C)(C)O)C(O)C2</smiles>

lachnumfuran A (128)

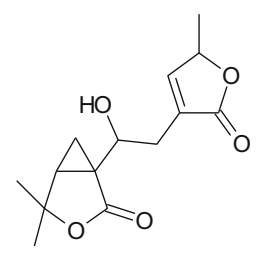

lachnumlactone A (129)<smiles>Cc1oc2c3c(c(O)c(Cl)c2c1Cl)CC(O)C(C)(C)O3</smiles>

chloromycorhizinol A (130)
2006). The insecticidal activity of paraherquamides against the milkweed bug, Oncopeltus fasciatus (Hemiptera, Lygaeidae), has also been reported (López-Gresa et al. 2006).

\section{Cochlioquinone A from Bipolaris sorokiniana}

B. sorokiniana (syn. Cochliobolus sativus, Pleosporaceae, Pleosporales) is one of the most notorious plant pathogens in warmer climates, and as the cause of southern leaf blotch, seedling blight, crown rot, node infections, head blight and black point on kernels; it is regarded as the economically most important foliar pathogen of wheat (Manamgoda et al. 2014). Static cultures in vermiculite-containing medium were incubated for 14 days at $25^{\circ} \mathrm{C}$ producing the yellow, crystalline $p$ benzoquinone derivative cochlioquinone $\mathrm{A}$ (148). This caused the immobilization of $50 \%$ of a C. elegans population after $16 \mathrm{~h}$ at a concentration of $135 \mu \mathrm{M}$ (Schaeffer et al. 1990). Cochlioquinone A was also obtained from $B$. leersiae (Barrow and Murphy 1972), which is a pathogen of Leersia and Setaria spp. (Poaceae, Manamgoda et al. 2014).

\section{Nematicidal ophiobolins}

Approximately $30 \mathrm{C}_{25}$ sesterterpenoids bearing a tricyclic 5-85 ring system (ophiobolins) have been isolated from fungi. Most of the producers are members of the genus Bipolaris (Pleosporales, Pleosporaceae), which include economically important phytopathogens such as B. oryzae (syn. Cochliobolus miyabeanus), the brown spot pathogen of rice B. maydis (C. heterostrophus) that causes southern corn leaf blight, and B. sorghicola, which causes leaf spot in sorghum. Even so, ophiobolin K (149) was initially isolated from $A s$ pergillus ustus JP 118 growing in a roller jar on a solid vermiculite-containing medium for 28 days at $25{ }^{\circ} \mathrm{C}$. This caused the immobilization of $50 \%$ of a C. elegans population after $16 \mathrm{~h}$ at a concentration of $10 \mu \mathrm{g} / \mathrm{ml}$, whereas 6epiophiobolin K (150) was inactive (Singh et al. 1991). Ophiobolins C (151) and M (152) were isolated from the necrotrophic pathogen $B$. maydis grown in static culture for 14 days at $25^{\circ} \mathrm{C}$. The $\mathrm{LD}_{50}$ values of compounds 149,151 , and 152 against $C$. elegans were 26,5 , and $13 \mu \mathrm{M}$, respectively. Ophobolins were shown to non-competitively inhibit the binding of ivermectin to membrane preparations from 
C. elegans, which accounts for an interaction at the ivermectin binding site (Tsipouras et al. 1996). ${ }^{7}$ The practical application of ophiobolins may be limited by their instability (Yun et al. 1988) and other diverse bioactivities (Au et al. 2000). For example, some ophiobolins are strongly phytotoxic, whereas others were harmless to plants (Yun et al. 1988; Evidente et al. 2006a, b). No structure-activity data are yet available to evaluate the relationship between the nematicidal and phytotoxic activities of these compounds.

\section{Bursaphelocides from an anamorphic fungus}

A taxonomically unidentified, sterile fungus (strain D1084) isolated from plant debris and grown in submerged culture for 6 days at $27^{\circ} \mathrm{C}$ was shown to produce the cyclodepsipeptides bursaphelocides A and B $(\mathbf{1 5 5}, \mathbf{1 5 6})$. Both compounds contain 2-hydroxy-3-methylpentanoic acid, isoleucine, $N$-methylvaline, $N$-methylalanine and $\beta$-alanine, but they differ in that compound $\mathbf{1 5 5}$ also contains proline, whereas in compound 156, this residue is 4-methylproline. ${ }^{8}$ The "cotton ball on fungal mat method" was used for bioassayguided fractionation of the culture broth. Compounds 155 and 156 caused $>96$ and $>98 \%$ mortality, respectively, when added to cultures of $B$. xylophilus at a concentration of $100 \mu \mathrm{g} / \mathrm{ml}$ per ball. Insecticidal activity was observed against Drosophila melanogaster larvae as well as weak phytotoxic activity in an alfalfa (Medicago sativa) seed germination test (Kawazu et al. 1993).

\section{A $\delta$-lactone from Trichoderma sp. YMF 1.00416}

The simple $\delta$-lactone 6- $n$-pentyl-2H-pyran-2-one (6-PAP) (157) represents the characteristic odoriferous volatile ("coconut flavor") of several Trichoderma spp. (Hypocreales, Hypocreaceae). A list of 77 isolates from 8 phylogenetically verified PAP-producing species has recently been compiled (Jeleń et al. 2014). Compound $\mathbf{1 5 7}$ is best known for its antagonistic activity toward a number of economically important phytopathogenic fungi (Gräfenhan 2006; Reino et al. 2008). More recently, organic extracts of the soil-borne fungus Trichoderma sp. YMF 1.00416 from a submerged culture grown at $28{ }^{\circ} \mathrm{C}$ were also tested for nematicidal activity. After $48 \mathrm{~h}$ exposure, the $\mathrm{LD}_{50}$ values against $P$. redivivus, $C$. elegans, and B. xylophilus were 69, 71, and $94 \mu \mathrm{g} / \mathrm{ml}$, respectively (Yang et al. 2012). Other Trichoderma-derived pyrones such as 6-(1'-pentenyl)-2H-pyran-2-one, massoialactone, $\delta$ decalactone, and viridepyronone should therefore be screened for nematicidal activity too (Reino et al. 2008).

\footnotetext{
${ }^{7}$ Notably, 6-epiophiobolin C (153) and 6-epiophiobolin M (154) did not display any nematicidal activity (Tsipouras et al. 1996).

${ }^{8}$ The configuration of the amino acids has not yet been determined.
}

\section{Endophytic ascomycetes producing 3-hydroxypropionic} acid

Submerged cultures of a number of endophytic fungi were screened for potential nematicidal activity against $B$. xylophilus using bioassay-guided fractionation. Five strains with the highest activities were used for the isolation and structural elucidation of the bioactive principles, including Phomopsis phaseoli (Diaporthaceae, Diaporthales) and Melanconium betulinum (Melanconidaceae, Diaporthales). However, the only nematicidal metabolite in all five isolates was identified as 3-hydroxypropionic acid (158). Notably, both of the species listed above may live either as plant pathogens or harmless endophytes (Schwarz et al. 2004). Because phytotoxic fungal isolates must not be used for integrated pest management, the pure compound should instead be considered for biocontrol applications. The structures of nematicidal metabolites from non-nematophagous ascomycetes are summarized in Fig. 3.

\section{Metabolites from non-nematophagous basidiomycetes}

\section{Metabolites from Cheimonophyllum candidissimum TA 8644}

Six bisabolane-type sesquiterpenoids were isolated from a culture filtrate of the xylophagous fungus Cheimonophyllum candidissimum (Agaricales, Cyphellaceae) after $168 \mathrm{~h}$ of submerged fermentation, namely cheimonophyllon E (90), cheimonophyllons A-D (159-162) and cheimonophyllal (163). The $\mathrm{LD}_{50}$ values of the compounds against $C$. elegans were $10 \mu \mathrm{g} / \mathrm{ml}$ (compounds 159 and 162), $25 \mu \mathrm{g} / \mathrm{ml}$ (compounds 160 and 163), $50 \mu \mathrm{g} / \mathrm{ml}$ (compound 161) ${ }^{9}$ and $>100 \mu \mathrm{g} / \mathrm{ml}$ (compound 93). Compound $\mathbf{1 5 9}$ was weakly mutagenic in the Ames test but no comparable data are available for the others. No phytotoxicity was observed, but the stability of compounds $159, \mathbf{1 6 0}, \mathbf{1 6 2}$, and $\mathbf{1 6 3}$ is limited by their reactivity (Stadler et al. 1994c, d). Asymmetric total synthesis of (+)-cheimonophyllon E (90) and (+)-cheimonophyllal (163) has been reported (Takao et al. 2002). An additional minor compound, the nematicidal $p$-menthan-type monoterpene 1,2-dihydroxymintlactone (164), was subsequently obtained as a colorless oil from $C$. candidissimum TA 8644. Its $\mathrm{LD}_{50}$ value against $C$. elegans was $25 \mu \mathrm{g} / \mathrm{ml}$ (Stadler et al. 1995g).

\section{Omphalotins from Omphalotus olearius TA 90170}

Mycelia from submerged cultures of the jack-o'-lantern mushroom Omphalotus olearius (Agaricales, Omphalotaceae)

\footnotetext{
${ }^{9}$ In solutions of cheimonophyllon C (161), a 1:1 mixture of the open form (161a) and the bicyclic acetal (161b) was present (Stadler et al. 1994c).
} 
<smiles>[R]CC1CC2=CC3=C(/C(O)=C/C(=O)/C=C/C=C/C=C/C(C)CC)C(=O)OC3(C)C(=O)C2=CO1</smiles>

$\mathrm{R}=\mathrm{H}=$ bulgarialactone $\mathrm{A}(\mathbf{1 3 1})$

$\mathrm{R}=\mathrm{OH}=$ bulgarialactone $\mathrm{B}(\mathbf{1 3 2})$
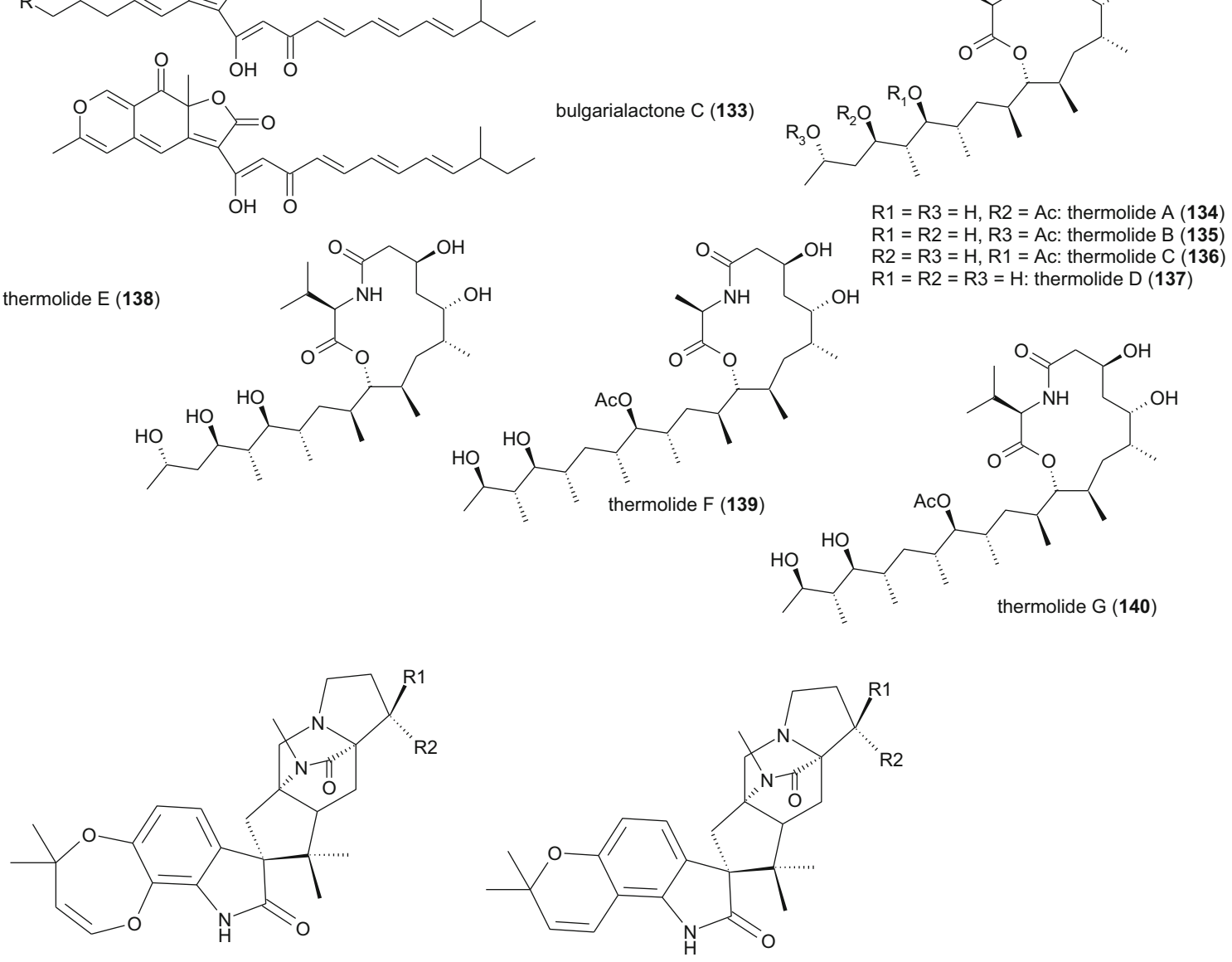

$\mathrm{R} 1=\mathrm{OH}, \mathrm{R} 2=\mathrm{CH}_{3}:$ paraherquamide $\mathrm{A}(\mathbf{1 4 1})$ $\mathrm{R} 1=\mathrm{H}, \mathrm{R} 2=\mathrm{H}:$ paraherquamide $\mathrm{B}(142)$ $\mathrm{R} 1=\mathrm{R} 2=\mathrm{CH}_{2}=:$ paraherquamide $\mathrm{C}(\mathbf{1 4 3})$ $\mathrm{R} 1=\mathrm{R} 2=\mathrm{CH}_{3} \mathrm{O}$-: paraherquamide $\mathrm{D}(\mathbf{1 4 4})$ $\mathrm{R} 1=\mathrm{H}, \mathrm{R} 2=\mathrm{CH}_{2}=:$ paraherquamide $\mathrm{E}(\mathbf{1 4 5})$<smiles>CC[C@H](C)[C@H](C)[C@H](O)C1=CC(=O)C2=C(OC3CCC4OC(C(C)(C)O)CCC4C3C2O)C1=O</smiles>

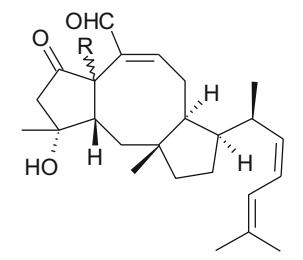

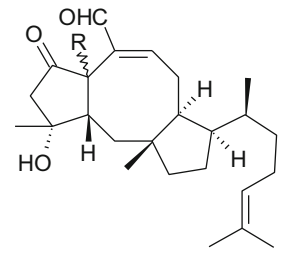

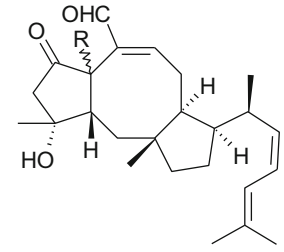

cochlioquinone A (148)

$\mathrm{R}=\beta \mathrm{H}=$ ophiobolin $\mathrm{K}(149) \quad \mathrm{R}=\beta \mathrm{H}=$ ophiobolin $\mathrm{C}(\mathbf{1 5 1}$

$\mathrm{R}=\beta \mathrm{H}=$ ophiobolin $\mathrm{M}(\mathbf{1 5 2})$ $\mathrm{R}=\alpha \mathrm{H}=$ epiophiobolin $\mathrm{K}(150) \mathrm{R}=\alpha \mathrm{H}=$ epiophiobolin $\mathrm{C}(153) \mathrm{R}=\alpha \mathrm{H}=$ epiophiobolin $\mathrm{M}(154)$

Fig. 3 Nematicidal metabolites from other non-nematophagous ascomycetes

yielded nine nematicidal cyclic dodecapeptides that were not present in the fruiting bodies. The main compound, omphalotin A (165), is a colorless oil that remains stable during isolation and storage. Remarkably, its $\mathrm{LD}_{50}$ against the plant-parasitic M. incognita was $2 \mu \mathrm{g} / \mathrm{ml}$, which is ten times more potent than the ivermectin standard. The saprotrophic nematode C. elegans was 35-fold less susceptible. Compound 165 was shown to protect cucumber and lettuce cultures from nematodes, with no evidence of additional phytotoxic, insecticidal, or antimicrobial activities. Cytotoxic effects were comparatively weak (Sterner et al. 1997; Mayer et al. 1997, 1999). Compound 165 contains a high proportion of methylated L-amino acids including sarcosine (methylglycine), methylvaline, and methylisoleucine (Sterner et al. 1997; Büchel et al. 1998). Three minor compounds, omphalotins $\mathrm{B}, \mathrm{C}$, and D (166-168), were obtained after prolonged fermentation. Their nematicidal activity was reported to be similar to omphalotin A but no data were presented 


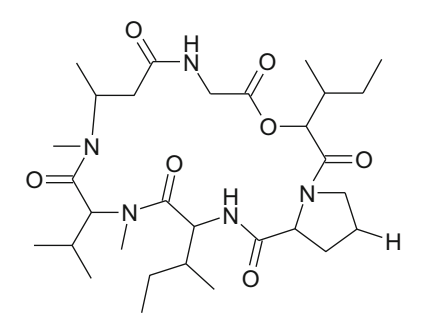

$\mathrm{R}=\mathrm{H}=$ bursapheleocide $\mathrm{A}$ (155) $\mathrm{R}=\mathrm{Me}=$ bursapheleocide $\mathrm{B}(\mathbf{1 5 6}$<smiles>C/C=C/CC(O)[C@H]1OC(C)(C)OC1C(C)/C=C/C(=O)OC(C)CCC(O)/C=C/C(=O)OC(C)C(O)/C=C/CC(C)OC(=O)c1c(O)cc(OC)c(OC)c1/C=C/C(=O)OC(C)C</smiles>

clonostachydiol (178)<smiles>CCC(C)/C=C/C=C(\C)C[C@H](C)/C=C/C=C/C1OC(=O)C(O)[C@H]2O[C@H]12</smiles>

6-n-pentyl-2H-pyran-2-one (6-PAP, 157)<smiles>O=C(O)CCO</smiles>

3-hydroxypropionic acid (158)

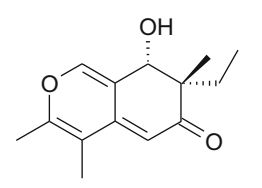

pseudohalonectrin A (175)<smiles></smiles>

pseudohalonectrin B (176)

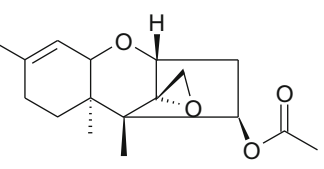

trichodermin (184)<smiles>CCC(O)C(O)C(=O)/C=C/CC(C)OC(=O)c1c(O)cc(OC)c(OC)c1/C=C/CC(C)O</smiles>

caryospomycin C (181)

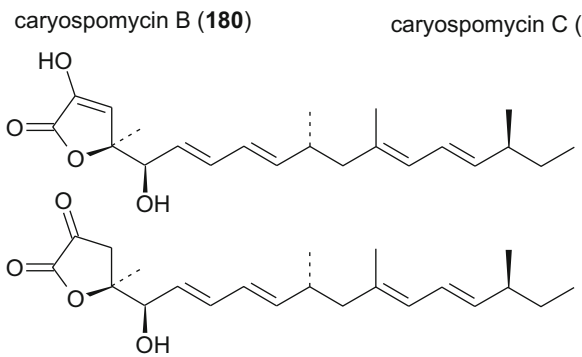

Fig. 3 continued.

(Büchel et al. 1998). Monokaryotic strains, which have been obtained from $O$. olearius TA 90170 protoplasts, yielded five additional hydroxylated compounds, omphalotins E-I (169-173), after 9 days of fermentation. Their nematicidal activity against $M$. incognita was highly selective, with $\mathrm{LD}_{50}$ values between 0.5 and $2.0 \mu \mathrm{g} / \mathrm{ml}$ (Liermann et al. 2009). One future challenge is to optimize fermentation conditions to improve the low yields of these compounds. In the meantime, a high-yielding method for solid-phase synthesis has been developed for compound $\mathbf{1 6 5}$ and other $N$-alkylated peptides using racemization-free triphosgene-mediated couplings (Thern et al. 2002).

\section{Illinitone A from Limacella illinita strain 99049}

Submerged cultures of the Dripping Slimecap Limacella illinita (Agaricales, Amanitaceae) yielded, after approximately 21 days, the colorless oil illinitone $\mathrm{A}(\mathbf{1 7 4})$. The $\mathrm{LD}_{50}$ value of this terpenoid compound against $C$. elegans was $25 \mu \mathrm{g} / \mathrm{ml}$. High concentrations $(333 \mu \mathrm{g} / \mathrm{ml})$ inhibited shoot and root growth in the garden cress (Lepidium sativum) and foxtail millet (Setaria italica) by $60 \%$ (Gruhn et al. 2007). Nematicidal metabolites from non-nematophagous basidiomycetes are summarized in Fig. 4.

\section{Outlook and perspectives}

More than 30,000 natural products have been isolated from fungi (Bérdy 2012), but fewer than 300 nematicidal compounds have been confirmed, representing just 280 producing species distributed over 150 genera (Laatsch 2014; Li and Zheng 2014). The screening of culture collections for nematicide-producing fungi could therefore yield more useful compounds than libraries of previously isolated natural products. The chemical structures of nematicidal metabolites are highly diverse, ranging from simple fatty acids and other organic acids to pyrones, lactones, benzoquinones, anthraquinones, furans, alkaloids, cyclodepsipeptides, peptaibiotics, and hybrid structures such as lactam-bearing macrolactones. It is therefore impossible to predict whether either a given fungal species or a particular fungal metabolite is likely to be nematicidal, and the activity against different nematode species may also vary. It is therefore essential to screen fungi and their metabolites against multiple economically important nematode species (Table 1), including common phytoparasites and nematodes that parasitize animals (e.g., H. contortus). The established model species $C$. elegans is often exquisitely sensitive toward nematicides, even primary metabolites such as fatty acids (Stadler et al. 1994a; Anke et al. 1995), although exceptions include oligosporon (2), which is inactive against 
Fig. 4 Nematicidal metabolites from non-nematophagous basidiomycetes<smiles>C=C(C(=O)CC(C)C)C(=O)C(=O)C1CCC(C)=CC1=O</smiles>

159<smiles>C=C(C(O)CC(C)C)C(O)C1CCC(C)=CC1=O</smiles><smiles>C=C1C(C(=O)CC(C)C)OC2C1CC[C@@](C)(O)C2O</smiles>

90<smiles>CC(C)CC(=O)C1OC2C(C=O)CC[C@@](C)(O)[C@@H]2O1</smiles><smiles>CC1C(=O)OC2C1CC[C@](C)(O)[C@H]2O</smiles><smiles>Cc1cc2c(cc1O)C(C)(O)[C@](C)(O)[C@H](O)C2=O</smiles>

164

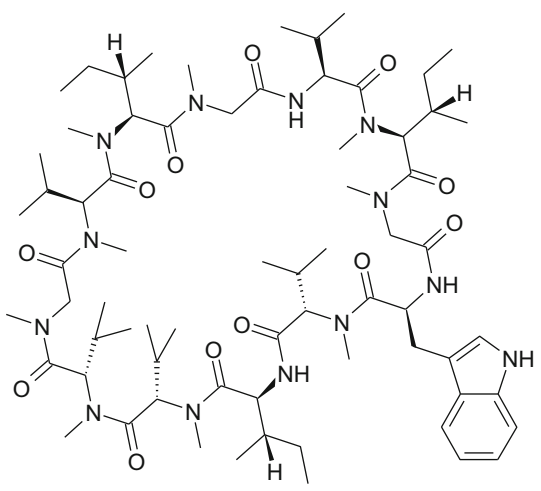

omphalotin A (165)

$\mathrm{R} 1=$<smiles>CCOC(=O)CC(C)(C)O</smiles>

$\mathrm{R} 2=\mathrm{OAC}$ $\mathrm{R} 3=\mathrm{OH}:$ omphalotin I (173)<smiles>C=C(C(O)C(=O)CC(C)C)C1CCC(C)=CC1O</smiles><smiles>C=C1C2CCC(C)=CC2O[C@](O)(CC(C)C)C1O</smiles>

$161 a$

$161 b$

cheimonophyllon A (159)

cheimonophyllon $\mathrm{B}$ (160)

cheimonophyllon $C$ (161a: open form; 161b: bicyclic acetal)

cheimonophyllon D (162)

chemonopphyllon $\mathrm{E}(\mathbf{9 0})$

cheimonophyllal (163)

1,2-dihydroxymintlactone (164)

illinitone (174)

dichomitin B (2\&,13-dihydroxyledol: 177)

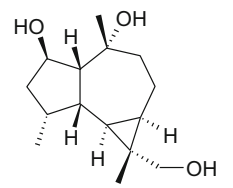

177

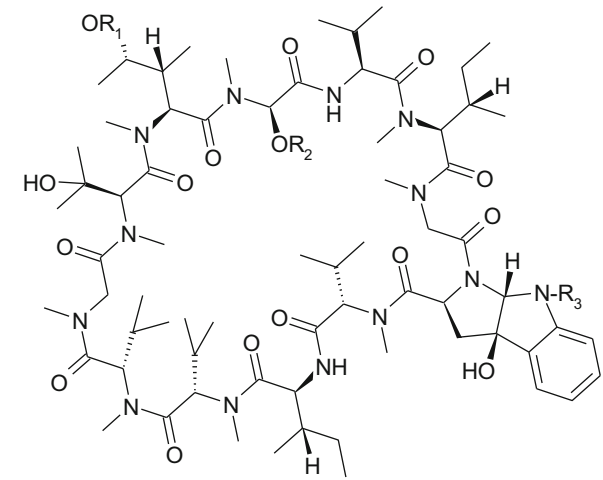

C. elegans but moderately active against $H$. contortus (Anderson et al. 1995).

In the second part of this review, 101 substances from nematophagous basidiomycetes and non-nematophagous fungi were introduced, some of which exhibit pronounced nematicidal activity. ${ }^{10}$ Thermolides A (134) and B (135) displayed potent nematicidal activity against $M$. incognita, B. xylophilus, and $P$. redivivus, comparable to that of the avermectin standard, but it remains difficult to produce large amounts of these

\footnotetext{
${ }^{10}$ Other nematicidal metabolites reported in the literature are not considered here because concentrations of $200-1000 \mu \mathrm{g} / \mathrm{ml}$ are required to achieve nematicidal effects.
}

compounds because the producers are thermophilic and cannot grow efficiently at temperatures below $45^{\circ} \mathrm{C}$, so cultivation conditions will need to be optimized. Other potent fungal nematicides discussed herein have only been isolated in minute quantities. This may reflect suboptimal fermentation conditions, as observed for the omphalotins (165-173), or physicochemical instability, as observed for epoxidized lachnumon $(109,119,120)$ and lachnumol derivatives (110), bulgarialactones (131-133), and ophiobolins K (149), M (151), and C (152).

Another challenge that must be addressed is that some nematicide-producing fungi are obligate phytopathogens (e.g., 
Table 1 Further lead metabolites from fungi exhibiting pronounced activity against plant-parasitic and intestinal nematodes

\begin{tabular}{|c|c|c|c|c|}
\hline Substance & Class & Producer & Effects & References \\
\hline $\begin{array}{l}\text { Pseudohalonectrin } \\
\text { A (175), B } \\
\text { (176) }\end{array}$ & Azaphilones & $\begin{array}{l}\text { Pseudohalonectria adversaria } \\
\text { YMF1.01019 } \\
\text { (Magnaporthaceae, } \\
\text { Magnaporthales) }\end{array}$ & $\begin{array}{l}>50 \% \text { mortality against } B . x y \text { lophilus } \\
\quad \text { after } 24 \mathrm{~h}(100 \mu \mathrm{g} / \mathrm{ml})\end{array}$ & Dong et al. 2006 \\
\hline $\begin{array}{l}2 \beta, 13- \\
\text { dihydroxyledol } \\
(=\text { dichomitin } \\
\mathrm{B}, \mathbf{1 7 7})\end{array}$ & Sesquiterpene & $\begin{array}{l}\text { Dichomitus squalens } \\
\quad \text { (Polyporales, Polyporaceae) }\end{array}$ & $\begin{array}{l}\mathrm{LC}_{50}=35,6 \mu \mathrm{g} / \mathrm{ml} \text { against } \\
\quad \text { B. xylophilus after } 24 \mathrm{~h}\end{array}$ & $\begin{array}{l}\text { Huang et al. } \\
2004\end{array}$ \\
\hline $\begin{array}{l}\text { Clonostachydiol } \\
\text { (178) }\end{array}$ & Macrodiolide & $\begin{array}{l}\text { Clonostachys cylindrospora } \\
\text { FH-A6607 (Hypocreales, } \\
\text { Bionectriaceae) }\end{array}$ & $\begin{array}{l}80-90 \% \text { reduction of fecal } H \text {. contortus in lambs after } \\
14 \text { days, } \\
\text { following subcutaneous admission of } 2.5 \mathrm{mg} / \mathrm{kg} \\
\text { clonostachydiol }\end{array}$ & $\begin{array}{c}\text { Grabley et al. } \\
1993\end{array}$ \\
\hline $\begin{array}{l}\text { Caryopsomycins } \\
\text { A-C (179-181) }\end{array}$ & $\begin{array}{l}\text { Resorcylic acid } \\
\text { lactones }\end{array}$ & $\begin{array}{l}\text { Caryospora callicarpa } \\
\text { YMF1.01026 (Pleosporales, } \\
\text { Zopfiaceae) }\end{array}$ & $\begin{array}{l}\mathrm{LC}_{50} \text { against } B . \text { xylophilus }[\mu \mathrm{g} / \mathrm{ml}] \text { after } 36 \mathrm{~h}: 103.1 \\
\quad(\mathbf{1 7 9}), 105.8 \\
\quad(\mathbf{1 8 0}) \text {, and } 105.1 \text { (181) }\end{array}$ & Dong et al. 2007 \\
\hline Nafuredin (182) & $\begin{array}{l}\text { Epoxy- } \delta \text {-lactone } \\
\text { with olefinic side } \\
\text { chain }\end{array}$ & $\begin{array}{l}\text { Aspergillus niger FT-0554 } \\
\quad \text { (Eutotiales, Aspergillaceae) }\end{array}$ & $\begin{array}{l}990 \% \text { reduction of } H \text {. contortus eggs after } 11 \text { days, } \\
\text { following one } \\
\text { single treatment of sheep with } 2 \mathrm{mg} / \mathrm{kg} \text { nafuredin } \\
\text { p.o.; } \\
\text { complete suppression of egg development following } \\
\text { a second treatment } 1 \text { week after first administration }\end{array}$ & $\begin{array}{l}\text { Ui et al. 2001; } \\
\text { Ōmura et al. } \\
2001\end{array}$ \\
\hline Nafuredin- $\gamma(\mathbf{1 8 3})$ & $\begin{array}{l}\gamma \text {-lactone with } \\
\text { olefinic side } \\
\text { chain }\end{array}$ & Aspergillus niger $\mathrm{FT}-0554$ & $\begin{array}{l}92 \% \text { reduction of } H \text {. contortus eggs } 11 \text { days after the } \\
\text { second treatment, conducted } 3 \text { weeks after first } \\
\text { administration }\end{array}$ & $\begin{array}{l}\text { Shiomi et al. } \\
2005\end{array}$ \\
\hline
\end{tabular}

Bipolaris spp.), whereas others are facultative phytopathogens that may also exist as endophytes. In these cases, the producers cannot be used as biocontrol agents, and the nematicidal compounds they biosynthesize must be isolated, e.g., cochlioquinone A (148) and 3-hydroxypropionic acid (158). Yang et al. (2010) have even suggested that the nematicidal mycotoxin trichodermin (184) could be isolated from Trichoderma strains producing it, but the use of mycotoxigenic fungi or pure mycotoxins in biocontrol had been discussed and argued against by Degenkolb et al. (2008) and Chaverri et al. (2015). Mycorrhizin A (106) and some of its derivatives from L. papyraceum $(\mathbf{1 0 7}, \mathbf{1 0 8}, \mathbf{1 1 7}, \mathbf{1 1 8}, \mathbf{1 2 1})$ as well as cheimonophyllon A (159) showed at least weak mutagenic activity in the Ames test.

Several promising examples of secondary metabolites from non-nematophagous fungi have also been discussed. Glasshouse and field trials with phylogenetically verified Trichoderma species producing either 6-PAP (157) (Gräfenhan 2006; Jeleń et al. 2014) or structurally related simple pyrones (Reino et al. 2008) should be conducted because their combined nematicidal and fungicidal properties are highly desirable for agricultural applications. Thermolides A (134) and B (135), omphalotins (165-173), ophiobolins ${ }^{11}(\mathbf{1 4 9}, \mathbf{1 5 1}, 152)$, bursaphelocides A (155) and B (156), illinitone A (174), pseudohalonectrins A (175) and B (176), dichomitin B (177),

\footnotetext{
${ }^{11}$ The nematicidal activity of most of the natural ophiobolins remains to be studied.
}

and caryopsomycins A-C (179-181) are excellent candidates or lead compounds for the development of biocontrol strategies for phytopathogenic nematodes, whereas paraherquamides (141-147), clonostachydiol (178), and nafuredins (182/183) offer promising leads for the development of formulations against the intestinal nematodes of ruminants (Table 1).

Acknowledgments We acknowledge financial support provided by the Hessian State Ministry of Higher Education, Research and the Arts (HMWK), including a generous grant for the LOEWE research center "Insect Biotechnology and Bioresources" to A.V. The authors thank Dr. Richard M. Twyman for editing of the manuscript.

\section{Compliance with ethical standards}

Conflict of interest The authors declare that they have no conflict of interest.

Open Access This article is distributed under the terms of the Creative Commons Attribution 4.0 International License (http:// creativecommons.org/licenses/by/4.0/), which permits unrestricted use, distribution, and reproduction in any medium, provided you give appropriate credit to the original author(s) and the source, provide a link to the Creative Commons license, and indicate if changes were made.

\section{References}

Anderson MG, Jarmin TB, Rickards RW (1995) Structures and absolute configurations of antibiotics of the oligosporon group from the 
nematode-trapping fungus Arthrobotrys oligospora. J Antibiot 48: 391-398

Anke H, Stadler M, Mayer A, Sterner O (1995) Secondary metabolites with nematicidal and antimicrobial activity from nematophagous fungi and Ascomycetes. Can J Bot 73(S1):932-939

Au TK, Chick WSH, Leung PC (2000) The biology of the ophiobolins. Life Sci 67:733-742

Barron GL (1977) The nematode-destroying fungi. Topics in mycobiology No. 1. Canadian Biological Publications Ltd, Guelph

Barron GL, Thorn RG (1987) Destruction of nematodes by species of Pleurotus. Can J Bot 65:774-778

Barrow KD, Murphy WS (1972) The structures of alboleersin and luteoleersin; the identity of luteoleersin with cochlioquinone A. J Chem Soc Perkin Trans 1:2837-2839

Bérdy J (2012) Thoughts and facts about antibiotics: where we are now and where we are heading. J Antibiot 65:385-395, Corrigendum in: J Antibiot 65:441

Büchel E, Martini U, Mayer A, Anke H, Sterner O (1998) Omphalotins B, C and D, nematicidal cyclopeptides from Omphalotus olearius absolute configuration of omphalotin A. Tetrahedron 54:5345-5352

Chaverri P, Branco-Rocha F, Jaklitsch W, Gazis R, Degenkolb T, Samuels GJ (2015) Systematics of the Trichoderma harzianum species complex and the re-identification of commercial biocontrol strains. Mycologia 107:558-590

Degenkolb T, Dieckmann R, Nielsen KF, Gräfenhan T, Theis C, Zafari D, Chaverri P, Ismaiel A, Brückner H, von Döhren H, Thrane U, Petrini O, Samuels GJ (2008) The Trichoderma brevicompactum clade: a separate lineage with new species, new peptaibiotics, and mycotoxins. Mycol Prog 7:177-219

Dong J, Zhou J, Li R, Zhou W, Zhu Y, Huang R, Zhang K (2006) New nematicidal azaphilones from the aquatic fungus Pseudohalonectria adversaria YMF1.01019. FEMS Microbiol Lett 264:65-69

Dong J, Zhu Y, Song H, Li R, He H, Liu H, Huang R, Zhou Y, Wang L, Cao Y, Zhang K (2007) Nematicidal resorcylides from the aquatic fungus Caryospora callicarpa YMF1.01026. J Chem Ecol 33:1115-1126

Evidente A, Andolfi A, Cimmino A, Vurro M, Fracchiolla M, Charudattan R (2006a) Herbicidal potential of ophiobolins produced by Drechslera gigantea. J Agric Food Chem 54:1779-1783

Evidente A, Andolfi A, Cimmino A, Vurro M, Fracchiolla M, Charudattan R, Motta A (2006b) Ophiobolin E and 8-epiophiobolin J produced by Drechslera gigantea, a potential mycoherbicide of weedy grasses. Phytochemistry 67:2281-2287

Gill M, Steglich W (1987) Pigments of fungi (macromycetes). Fortschr Chem Org Naturst 51:1-297

Grabley S, Hammann P, Thiericke R, Wink J, Philips S, Zeeck A (1993) Secondary metabolites by chemical screening. 21. Clonostachydiol, a novel anthelmintic macrodiolide from the fungus Clonostachys cylindrospora (strain FH-A 6607). J Antibiot 46:343-345

Gräfenhan T (2006) Epidemiology and biological control of latent grapevine trunk diseases. Dissertation, Humboldt University of Berlin

Gruhn N, Schoettler S, Sterner O, Anke T (2007) Biologically active metabolites from the basidiomycete Limacella illinita (Fr.) Murr. Z Naturforsch 62c:808-812

Guo J-P, Zhu C-Y, Zhang C-P, Chu Y-S, Wang Y-L, Zhang J-X, Wu D-K, Zhang K-Q, Niu X-M (2012) Thermolides, potent nematocidal PKS-NRPS hybrid metabolites from thermophilic fungus Talaromyces thermophilus. J Am Chem Soc 134:20306-20309

Hart DJ, Hunag H-C (1988) Total synthesis of ( \pm )-pleurotin and ( \pm )dihydropleurotin acid. J Am Chem Soc 110:1634-1635

Houbraken J, de Vries RP, Samson RA (2014) Modern taxonomy of biotechnologically important Aspergillus and Penicillium species. Adv Appl Microbiol 86:199-249

Huang Z, Dan Y, Huang Y, Lin L, Li T, Ye W, Wie X (2004) Sesquiterpenes from the mycelial cultures of Dichomitus squalens. J Nat Prod 67:2121-2123
Jeleń H, Błaszczyk L, Chełkowski J, Rogowicz K, Strakowska J (2014) Formation of 6-n-pentyl-2 $H$-pyran-2-one (6-PAP) and other volatiles by different Trichoderma species. Mycol Prog 13:589-600

Kawazu K, Murakami T, Ono Y, Kanzaki H, Kobayashi A, Mikawa T, Yoshikawa N (1993) Isolation and characterization of two novel nematicidal depsipeptides from an imperfect fungus, strain DI084. Biosci Biotechnol Biochem 57:98-101

Kirk PM, Cannon PF, Minter DW, Stalpers JA (2008) Dictionary of the fungi, 10th edn. CABI International, Wallingford

Koziak AT, Cheng KC, Thorn RG (2007) Phylogenetic analyses of Nematoctonus and Hohenbuehelia (Pleurotaceae). Can J Bot 85: $762-773$

Kwok OCH, Plattner R, Weisleder D, Wicklow DT (1992) A nematicidal toxin from Pleurotus ostreatus NRRL 3526. J Chem Ecol 18:127-136

Laatsch H (2014) Antibase 2014 SciDex v. 1.2.495-the natural compounds identifier. Wiley, Weinheim

Li G-H, Zhang K-Q (2014) Nematode-toxic fungi and their nematicidal metabolites. In: Hyde KD, Zhang K-Q (eds) Nematode-trapping fungi. Springer, Dordrecht Heidelberg, New York, London, pp 313-375

Li G, Wang X, Zheng L, Li L, Huang R, Zhang K (2007) Nematicidal metabolites from the fungus Pleurotus ferulae Lenzi. Ann Microbiol 57:527-529

Liermann JC, Opatz T, Kolshorn H, Antelo L, Hof C, Anke H (2009) Omphalotins E-I, five oxidatively modified nematicidal cyclopeptides from Omphalotus olearius. Eur J Org Chem 1256-1262

Liu YJ, Liu Y, Zhang KQ (2008) Xanthothone, a new nematicidal Ncompound from Coprinus xanthothrix. Chem Nat Compd 44:203-205

López-Gresa MP, González MC, Ciavatta L, Ayala I, Moya P, Primo J (2006) Insecticidal activity of paraherquamides, including paraherquamide $\mathrm{H}$ and paraherquamide I, two new alkaloids isolated from Penicillium cluniae. J Agric Food Chem 54:2921-2925

Luo H, Mo M, Huang X, Li X, Zhang K (2004) Coprinus comatus: a basidiomycete fungus forms novel spiny structures and infects nematode. Mycologia 96:1218-1225

Luo H, Liu Y, Fang L, Li X, Tang N, Zhang K (2007) Coprinus comatus damages nematode cuticles mechanically with spiny balls and produces potent toxins to immobilize nematodes. Appl Environ Microbiol 73:3916-3923

Manamgoda DS, Rossman AY, Castlebury LA, Crous PW, Madrid H, Chukeatirote E, Hyde KD (2014) The genus Bipolaris. Stud Mycol 79:221-288

Mang SM, Figliuolo G (2010) Species delimitation in Pleurotus eryngii species-complex inferred from ITS and EF- $1 \alpha$ gene sequences. Mycology 1:269-280

Mayer A, Anke H, Sterner O (1997) Omphalotin, a new cyclic peptide with potent nematicidal activity from Omphalotus olearius. I. fermentation and biological activity. Nat Prod Lett 10:25-32

Mayer A, Kilian M, Hoster B, Sterner O, Anke H (1999) In-vitro and invivo nematicidal activities of the cyclic dodecapeptide omphalotin A. Pestic Sci 55:27-30

Morris EE, Hajek AE (2014) Eat or be eaten: fungus and nematode switch off as predator and prey. Fungal Ecol 11:114-121

Niu X, Chen L, Yue Q, Wang B, Zhang J, Zhu C, Zhang K, Bills GF, An Z (2014) Characterization of thermolide biosynthetic genes and a new thermolide from sister thermophilic fungi. Org Lett 16:3744-3747

Ōmura S, Miyadera H, Ui H, Shiomi K, Yamaguchi Y, Masuma R, Nagamitsu T, Takano D, Sunazuka T, Harder A, Kölbl H, Namikoshi M, Miyoshi H, Sakamoto K, Kita K (2001) An anthelmintic compound, nafuredin, shows selective inhibition of complex I in helminth mitochondria. Proc Acad Natl Sci USA 98:60-62

Ostlind DA, Cifelli S, Mickle WG, Smith SK, Ewanciw DV, Rafalko B, Felcetto T, Misura A (2006) Evaluation of broad-spectrum anthelmintic activity in a novel assay against Haemonchus contortus Trichostrongylus colubriformis and T. sigmodontis in the gerbil Meriones unguiculatus. J Helminthol 80:393-396 
Palizi P, Goltapeh EM, Pourjam E, Safaie N (2009) Potential of oyster mushrooms for the biocontrol of sugar beet nematode (Heterodera schachtii). J Plant Protect Res 49:27-33

Reino JL, Guerrero RF, Hernández-Galán R, Collado IG (2008) Secondary metabolites from species of the biocontrol agent Trichoderma. Phytochem Rev 7:89-123

Schaeffer JM, Frazier EG, Bergstrom AR, Williamson JM, Liesch JM, Goetz MA (1990) Cochlioquinone A, a nematocidal agent which competes for specific $\left[{ }^{3} \mathrm{H}\right]$ ivermectin binding sites. J Antibiot 43 : $1179-1182$

Schwarz M, Köpcke B, Weber RWS, Sterner O, Anke H (2004) 3Hydroxypropionic acid as a nematicidal principle in endophytic fungi. Phytochemistry 65:2239-2245

Shan R, Stadler M, Sterner O, Anke H (1996) New metabolites with nematicidal and antimicrobial activities from the ascomycete Lachnum papyraceum (Karst.) Karst. VIII. Isolation, structure determination and biological activities of minor metabolites structurally related to mycorrhizin A. J Antibiot 49:447-452

Shiomi K, Ui H, Suzuki H, Hatano H, Nagamitsu T, Takano D, Miyadera H, Yamashita T, Kita K, Miyoshi H, Harder A, Tomoda H, Ōmura S (2005) A $\gamma$-lactone form nafuredin, nafuredin- $\gamma$, also inhibits helminth complex I. J Antibiot 58:50-55

Shipley SM, Barr AL, Graf SJ, Collins RP, McCloud TG, Newman DJ (2006) Development of a process for the production of the anticancer lead compound pleurotin by fermentation of Hohenbuehelia atrocaerulea. J Ind Microbiol Biotechnol 33:463-468

Singh SB, Smith JL, Sabnis GS, Dombrowski AW, Schaeffer JM, Goetz MA, Bills GF (1991) Structure and conformation of ophiobolin K and 6-epiophiobolin K from Aspergillus ustus as a nematocidal agent. Tetrahedron 47:6931-6938

Stadler M, Anke H, Arendholz WR, Hansske F, Anders U, Sterner O, Bergquist K-E (1993a) Lachnumon and lachnumol a, new metabolites with nematicidal and antimicrobial activities from the ascomycete Lachnum papyraceum (Karst.) karst. I. Producing organism, fermentation, isolation and biological activities. J Antibiot 46:961-967

Stadler M, Anke H, Bergquist KE, Sterner O (1993b) Lachnumon and lachnumol a, new metabolites with nematicidal and antimicrobial activities from the ascomycete Lachnum papyraceum (Karst.) Karst. II. Structural elucidation. J Antibiot 46:968-971

Stadler M, Mayer A, Anke H, Sterner O (1994a) Fatty acids and other compounds with nematicidal activity from cultures of basidiomycetes. Planta Med 60:128-132

Stadler M, Sheldrick WS, Dasenbrock J, Steglich W, Anke H (1994b) Antibiotics from the nematode-trapping basidiomycete Nematoctonus robustus. Nat Prod Lett 4:209-216

Stadler M, Anke H, Sterner O (1994c) New nematicidal and antimicrobial compounds from the basidiomycete Cheimonophyllum candidissimum (Berk \& Curt.) Sing. I. Producing organism, fermentation, isolation, and biological activities. J Antibiot 47:1284-1289

Stadler M, Anke H, Sterner O (1994d) Six new antimicrobial and nematicidal bisabolanes from the basidiomycetes Cheimonophyllum candidissimum. Tetrahedron 50:12649-12654

Stadler M, Anke H, Sterner O (1995a) Metabolites with nematicidal and antimicrobial activities from the ascomycete Lachnum papyraceum (Karst.) Karst. III. Production of novel isocoumarin derivatives, isolation, and biological activities. J Antibiot 48:261-266

Stadler M, Anke H, Sterner O (1995b) New metabolites with nematicidal and antimicrobial activities from the ascomycete Lachnum papyraceum (Karst.) Karst. IV. Structural elucidation of novel isocoumarin derivatives. J Antibiot 48:267-270
Stadler M, Anke H, Sterner O (1995c) Metabolites with nematicidal and antimicrobial activities from the ascomycete Lachnum papyraceum (Karst.) Karst. V. Production, isolation and biological activities of bromine-containing mycorrhizin and lachnumon derivatives and four additional new bioactive metabolites. J Antibiot 48:149-153

Stadler M, Anke H, Sterner O (1995d) New metabolites with nematicidal and antimicrobial activities from the ascomycete Lachnum papyraceum (Karst.) Karst. VII. Structure determination of brominated lachnumon and mycorrhizin a derivatives. J Antibiot 48:158-161

Stadler M, Anke H, Shan R, Sterner O (1995e) New metabolites with nematicidal and antimicrobial activities from the ascomycete Lachnum papyraceum (Karst.) Karst. VI. Structure determination of non-halogenated metabolites structurally related to mycorrhizin A. J Antibiot 48:154-157

Stadler M, Anke H, Dekermendijan K, Reiss R, Sterner O, Witt R (1995f) New azaphilones from fruit bodies and mycelial cultures of the ascomycete Bulgaria inquinans Fr. Nat Prod Lett 7:7-14

Stadler M, Fouron J-Y, Sterner O, Anke H (1995g) 1,2Dihydroxymintlactone, a new nematicidal monoterpene isolated from the basidiomycete Cheimonophyllum candidissimum (Berk \& Curt.) Sing. Z Naturforsch 50c:473-475

Sterner O, Etzel W, Mayer A, Anke H (1997) Omphalotin, a new cyclic peptide with potent nematicidal activity from Omphalotus olearius. II. Isolation and structure determination. Nat Prod Lett 10:33-38

Takao K, Tsujita T, Hara M, Tadano K (2002) Asymmetric total syntheses of (+)-cheimonophyllon E and (+)-cheimonophyllal. J Org Chem 67:6690-6698

Thern B, Rudolph J, Jung G (2002) Total synthesis of the nematicidal cyclododecapeptide omphalotin A by using racemization-free triphosgene-mediated couplings in the solid phase. Angew Chem Int Ed Engl 41:2307-2309

Thorn RG, Barron GL (1984) Carnivorous mushrooms. Science 224:76-78

Thorn RG, Moncalvo J-M, Reddy CA, Vilgalys R (2000) Phylogenetic analyses and the distribution of nematophagy support a monophyletic Pleurotaceae within the polyphyletic pleurotoid-lentinoid fungi. Mycologia 92:241-252

Tsipouras A, Adefarati AA, Tkacz JS, Frazier EG, Rohrer SP, Birzin E, Rosegay A, Zink DL, Goetz MA, Singh SB, Schaeffer JM (1996) Ophiobolin $\mathrm{M}$ and analogues, noncompetitive inhibitors of ivermectin binding with nematocidal activity. Bioorg Med Chem 4:531-536

Ui H, Shiomi K, Yamaguchi Y, Masuma R, Nagamitsu T, Takano D, Sunazuka T, Namikoshi M, Ōmura S (2001) Nafuredin, a novel inhibitor of NADH-fumarate reductase, produced by Aspergillus niger FT-0554. J Antibiot 54:234-238

Welsh SJ, Williams RR, Birmingham A, Newman DJ, Kirkpatrick DL, Powis G (2003) The thioredoxin redox inhibitors 1-methylpropyl 2imidazolyl disulfide and pleurotin inhibit hypoxia-induced factor $1 \alpha$ and vascular endothelial growth factor formation. Mol Cancer Ther 2:235-243

Yang Z-S, Li G-H, Zhao P-J, Zheng X, Luo S-L, Li L, Niu X-M, Zhang K-Q (2010) Nematicidal activity of Trichoderma spp. and isolation of an active compound. World J Microbiol Biotechnol 26:22972302

Yang Z, Yu Z, Lei L, Xia Z, Shao L, Zhang K, Li G (2012) Nematicidal effect of volatiles produced by Trichoderma sp. J Asia Pac Entomol $15: 647-650$

Yun C-H, Sugawara F, Strobel GA (1988) The phytotoxic ophiobolins produced by Drechslera oryzae, their structures and biological activity on rice. Plant Sci 54:237-243 